\title{
The Relationship Between Some Anemia Parameters and Hepcidin Level in Anaplasma phagocytophilum Seropositive Dogs
}

\author{
Anaplasma phagocytophilum Seropozitif Olan Köpeklerde Baそฺ Anemi Parametreleri ile Hepsidin Düzeyinin İliskisi
}

\section{Menekşe DENİZ1 ${ }^{(i)}$, Şima ŞAHİNDURAN*iD}

\author{
${ }^{1}$ Burdur Mehmet Akif Ersoy University, Faculty of Veterinary Medicine, Department of Internal Medicine, Burdur, \\ Turkey
}

\begin{abstract}
Anaplasmosis in dog is caused by Anaplasma phagocytophilum, a gram-negative, mandatory intracellular bacteria. It is transmitted through vector tick. Clinically, the acute bacterial phase is the most common in dogs. Animals with clinical disease due to acute infection often have vague symptoms of the disease, including fever, drowsiness, weakness, loss of appetite, and muscle pain. Hepcidin, on the other hand, is a peptide hormone and also plays a role as a type II acute phase reactant and regulator of iron metabolism. The aim of the study was to evaluate the relationship between hepcidin and some anemia parameters in Anaplasma phagocytophilum seropositive dogs and to learn about the use of hepcidin as a biomarker. In the study, a total of $30 \mathrm{dogs}, 20$ of which were positive for Anaplasma phagocytophilum, and 10 healthy dogs in the control group were used. In both groups, complete blood counts were performed. Hepcidin, iron, ALT, AST and ALP values were also measured in serum samples collected. When the parameters of the control and study groups were evaluated, the difference between iron, hepcidin, ALT, AST, ALP values were found statistically significant $(\mathrm{p}<0.05)$. As a result, hepcidin values between the two groups were statistically significant $(\mathrm{p}<0.05)$ and it was concluded that hepcidin could be used as a biomarker in the diagnosis of anaplasma infection in dogs with other parameters.
\end{abstract}

Keywords: Hepcidin, Anaplasma, Anemia.

Öz: Köpek anaplazmozisi, gram negatif, zorunlu hücre içi bir bakteri olan Anaplasma phagocytophilum' dan kaynaklanmaktadır. Bu bakteri vektör kene aracılığı ile bulaşma sağlanmaktadır. Akut enfeksiyona bağlı klinik hastalığ1 olan hayvanlarda genellikle ateş, uyuşukluk, halsizlik, istahsızlık ve kas ağrıları da dahil olmak üzere hastalığın belirsiz belirtileri görülmektedir. Hepsidin ise, peptid yapıda bir hormone olup aynı zamanda tip II akut faz reaktanı ve demir metabolizmasında düzenleyici olarak rol almaktadır. Araştırmanın amacı Anaplasma phagocytophilum seropozitif köpeklerde bazı anemi parametreleri ile hepsidin arasındaki ilişkiyi değerlendirmek ve hepsidinin biyomarker olarak kullanımı hakkında bilgi edinmektir. Çalışmada Anaplasma phagocytophilum yönünden pozitif olan 20 adet, kontrol grubunda da sağlıklı 10 adet olmak üzere toplam 30 adet köpek kullanılmıştır. Her iki gruptaki köpeklerden alınan kanlarda tam kan sayımı yapılmıştır. Ayrıca hepsidin, demir, ALT, AST ve ALP değerleri toplanan serum örneklerinde ölçülmüştür. Kontrol ve çalışma gruplarının parametreleri değerlendirildiğinde demir, hepsidin, ALT, AST, ALP değerleri arasındaki fark istatistiksel olarak anlamlı bulundu $(\mathrm{p}<0.05)$. Sonuç olarak iki grup arasında hepsidin değerleri istatistiksel açıdan önemli $(\mathrm{p}<0.05)$ bulunarak, köpeklerde anaplasma enfeksiyonu teşhisinde hepsidinin diğer parametreler eşliğinde biyomarker olarak kullanılabileceği kanaatine varılmıştır.

\begin{tabular}{ll}
\hline Anahtar Kelimeler: Hepsidin, Anaplasma, Anemi. & \\
\hline${ }^{*}$ Corresponding author : Şima ŞAHINDURAN & e-mail : sahinduran@mehmetakif.edu.tr \\
Geliş tarihi / Received: 29.09 .2020 & Kabul tarihi / Accepted: 16.11 .2020 \\
\hline
\end{tabular}

\section{Introduction}

Members of the Anaplasmateceae family are gramnegative compulsory intracellular pleomorphic cocci and are proliferated in membrane-bound vacuoles (morula) in the cytoplasm of the hematopoietic specific host cell or invertebrates
(Lai et al., 2009). Although these bacteria are not contagious, they are transmitted by vector ticks or trematodes (Rikihisa, 2006). I. ricinus tick species are responsible for the contamination in Turkey (Lee et al., 2003). The disease-causing species in dogs are A. phagocytophilum and A. platys, and A. phagocytophilum is the etiological agent of $\mathrm{dog}$ 
granulocytic anaplasmosis (CGA) that previously known as granulocytic ehrlichiosis (Tunç and Aktaş, 2016; Cockwill et al., 2009). Although the most common clinical findings of $A$. phagocytophilum are not specific; it is drowsiness, anorexia and fever. Other findings are pale mucosa, gastrointestinal symptoms (vomiting, diarrhea), slightly enlarged lymph nodes, tachypnea and surface bleeding (petechia, melena or nosebleeds). Rarely, collapse, mild cough, uveitis, limb edema and polydipsia / polyuria have been reported (Eberts et al., 2011; Sainz et al., 2015). A. phagocytophilum infection may trigger some immunopathies such as immune-mediated thrombocytopenia / anemia (Kohn et al., 2008). Iron metabolism is significantly linked to host defense responses. In response to inflammatory stimuli, macrophages reduce iron absorption and affect growth rates to protect against pathogens. Cytokines such as TNF- $\alpha$ (tumor necrosis factor alpha), IL-1 (interleukin-1), IL-6 (interleukin-6), iron intake network, iron storage $(\mathrm{H}-$ and $\mathrm{L}$ ferritin) and effect in iron regulatory system (Falzacappa and Muckenthaler, 2005; Ganz, 2006).

In the acute phase of the inflammation, proteins that show significant changes in blood levels are called acute phase protein (APP). Acute phase proteins are used to assess the response of the body's immune system to inflammation or trauma (Muratta et al. 2004; Petersen et al. 2004). Their secretion is regulated by the proinflamatory cytokines, in particular interleukin 6 (IL-6) (Muratta et al. 2004).

Hepcidin is a hormone that has multiple functions and a peptide structure (Krause et al. 2000). Hepcidin has been studied in human and many animal species (mice, rats, pigs, fish, dogs) to date. In a study on healthy canine tissues, hepcidin was found to be secreted mostly in the liver and less in the lungs and kidneys but not in other tissues (Fry et al., 2004). Hepatic hepcidin production is under the influence of many stimulants such as low levels of iron and erythropoietic activation. Also some cytokines, especially IL-6, increase the level of hepcidin (Kemna et al., 2005). Hepcidin also assists host defense due to its direct antimicrobial properties (Falzacappa and Muckenthaler, 2005;
Wessling-Resnick, 2010). Inflammation states stimulate hepcidin production and increase its release, leading to a decrease in iron secretion from macrophages and a decrease in plasma iron levels (Coyne DW, 2011; Nemeth et al., 2003). In addition, the iron balance in the body is balanced by hepcidin. In iron deficiency, hepcidin level increases and there is a negative correlation between iron deficiency and hepcidin (Coyne, 2011).

The aim of this study was to investigate the relationship between anemia and iron level in blood with hepcidin level in infected dogs with A. phagocytophilum.

\section{Material and Merhods}

This research was carried out on the basis of the permission of Mehmet Akif Ersoy University Local Animal Ethics Committee dated 10.10.2018 and numbered 447.

The research material consisted of dogs brought to the Vetopya Veterinary Clinic in Antalya Döşemealtı District for vaccination, examination, treatment and control. The owners of the animals in the study were informed about the applications. Blood samples were collected by considering clinical symptoms and criteria such as weakness, anorexia, weight loss and weakness, Polydipsia / Polyuria and anemia in animals to form the study group.

Antibody immunochromatographic assay CaniV-4 (Dirofloria immitis antigen, Ehrlichia canis antibody test, Borrelia burgdorferi antibody test and Anaplasma phogocytophilum antibody detection) Kit (BioNote, Inc. Repubc of) were used to identify anaplasma phagocytophilum seropositive dogs. Only dogs with A. phagocytophilum seropositive were included in the study. According to the above-mentioned criteria, only anaplasma-positive 20 blood samples were collected. These samples were gathered out of different breed dogs with 6 females and 14 males (aged 7 months -8 years). Animals in control grup consist of 4 females and 6 males healthy dogs. 
Complete blood counts of the dogs were performed in both groups (Diatron Abacus Junior Vet Hematology Analyzer, S / N 130702 model). The blood samples were coagulated, and their sera were separated in the cooled centrifuge at 4000 rpm for $5 \mathrm{~min}$. The resulting serum samples were transferred to Eppendorf tubes $(1.5 \mathrm{ml})$ evenly using micropipette. The tubes were recorded with their sample numbers, and stored at $-20^{\circ} \mathrm{C}$ until used.

In addition, Fe, ALP, AST and ALT values were measured in serum samples collected. In the results obtained, Fe, ALP, AST and ALT values of the animals in the study and control groups were compared. Biochemical analysis was done with Gesan Chem 200-1102422 (Italy) autoanalysor device.

Hepcidin values in blood serum were measured by ELISA (Enzyme-Linked Immunosorbent Assay) method. Dog specific hepcidin ELISA kits (YLBiont, Shanghai yl Biotech Co., Ltd. (China) were used in the study. In order to increase the reliability of the study, serum samples were run in duplicate. Microsoft Office ${ }^{\circledR}$ Excel program was used in calculations after ELISA measurement. The data obtained at the end of the process were calculated by the calculation method in the kit and slope graphics were created and samples were calculated in accordance with this slope.

\section{Statistical Analysis}

The findings were evaluated using the IBM SPSS 22.0 for Windows package program. The ShapiroWilk test was used when the data was applied to the normal distribution. Due to the normal distribution of data, binary group comparisons were determined by the Mann Whitney $\mathrm{U}$ test. $\mathrm{p}$ $<0.05$ value limit was accepted.

Table 1. Mean values of some hematological parameters of cats in study and control groups.

\begin{tabular}{lccc}
\hline & Study group (n=20) & Control group(n=10) & \\
Parametre & $\bar{x} \pm s s$ & $\bar{x} \pm s s$ & $\boldsymbol{p}$ \\
\hline WBC $\left(10^{9} / \mathrm{L}\right)$ & $m$ (min-max) & $m$ (min-max) & 0.000 \\
& $34.48 \pm 30.07^{\mathrm{a}}$ & $11.24 \pm 2.43^{\mathrm{b}}$ & \\
LYMPH\# $\left(10^{9} / \mathrm{L}\right)$ & $25.22(9.60-117.50)$ & $10.71(8.40-17.30)$ & 0.000 \\
& $14.42 \pm 30.07^{\mathrm{a}}$ & $2.40 \pm 1.62^{\mathrm{b}}$ & \\
MON\# $\left(10^{9} / \mathrm{L}\right)$ & $25.22(9.60-117.50)$ & $2.07(0.00-6.10)$ & 0.000 \\
& $1.56 \pm 1.56^{\mathrm{a}}$ & $0.28 \pm 0.18^{\mathrm{b}}$ & 0.061 \\
GRAN\# $\left(10^{9} / \mathrm{L}\right)$ & $1.00(0.12-6.20)$ & $0.30(0.00-0.70)$ & \\
& $18.23 \pm 15.50^{\mathrm{a}}$ & $9.73 \pm 3.98^{\mathrm{a}}$ & 0.003 \\
RBC $\left(10^{9} / \mathrm{L}\right)$ & $16.45(0.00-66.40)$ & $10.57(0.00-14.90)$ & 0.645 \\
& $4.52 \pm 1.50^{\mathrm{a}}$ & $6.27 \pm 2.39^{\mathrm{b}}$ & \\
HGB $(\mathrm{g} / \mathrm{dL})$ & $4.24(2.36-8.33)$ & $6.96(00.00-8.51)$ & 0.422 \\
& $5.66 \pm 4.20^{\mathrm{a}}$ & $5.91 \pm 7.66^{\mathrm{a}}$ & \\
HCT $(\%)$ & $4.75(0.00-11.70)$ & $0.00(0.00-15.67)$ & 0.001 \\
PLT $\left(10^{9} / \mathrm{L}\right)$ & $8.62 \pm 12,25^{\mathrm{b}}$ & $18.49 \pm 23,99^{\mathrm{b}}$ & \\
& $0.00(0.00-30.02)$ & $0.00(0.00-50.87)$ & \\
\hline
\end{tabular}

WBC: Leukocyte, LYM: Lymphocyte, MON: Monocytes, NEU: Neutrophil, RBC: Erythrocyte, HGB: Hemoglobin, HCT: Hematocrit, MCV: Mean cell volume, PLT: Platelets.

There is a statistical difference between columns containing different letters $(\mathrm{p}<0.05)$.

\section{Results}

The blood samples taken from the dogs in both groups were analyzed in the blood counting device 
without delay and hematology results were obtained.

While there were no differences in the granulocyte, hemoglobin and hematocrit between the two groups ( $p>0.05)$, difterences between leukocyte $(\mathrm{p}<0.05), \quad$ lymphocyte $(\mathrm{p}<0.05), \quad$ monocyte $(\mathrm{p}<0.05)$, erythrocyte $(\mathrm{p}<0.05)$ and platelet $(p<0.05)$ values were significant between two groups (Table 1).

When the parameters of the control and study groups were evaluated, the difference between iron $(\mathrm{p}<0.05)$, hepcidin $(\mathrm{p}<0.05)$, ALT $(\mathrm{p}<0.05)$, AST $(p<0.05)$, ALP $(p<0.05)$ values were found statistically significant. Iron, hepcidin, ALT, AST and ALP values are shown in Table 2.

Table 2. Mean values of iron, hepcidin, ALT, AST, ALP values between study and control groups.

\begin{tabular}{lccc}
\hline & Study group (n=20) & Control group (n=10) & \\
Parametre & $\bar{x} \pm s s$ & $\bar{x} \pm s s$ & $\boldsymbol{p}$ \\
\hline Fe $(\boldsymbol{\mu g} / \mathbf{d L})$ & $m($ min-max $)$ & $m$ (min-max) & 0.000 \\
& $72.50 \pm 17.02^{\mathrm{a}}$ & $145.70 \pm 56.51^{\mathrm{b}}$ & \\
ALT (U/L) & $74.50(52.00-101.00)$ & $130.00(85.00-251.00)$ & 0.000 \\
& $157.00 \pm 62.91^{\mathrm{a}}$ & $55.64 \pm 13.23^{\mathrm{b}}$ & \\
AST (U/L) & $176.00(31.00-281.00)$ & $54.10(38.00-79.10)$ & 0.000 \\
& $171.10 \pm 98.43^{\mathrm{a}}$ & $37.01 \pm 14.09^{\mathrm{b}}$ & 0.000 \\
ALP (U/L) & $131.00(46.50-395.20)$ & $32.60(24.60-65.00)$ & \\
& $423.23 \pm 243.92^{\mathrm{a}}$ & $153.80 \pm 52.02^{\mathrm{b}}$ & 0.000 \\
Hepsidin (ng/ml) & $350.00(71.00-1015.00)$ & $123.00(112.00-270.00)$ & \\
& $36.16 \pm 12.99^{\mathrm{a}}$ & $11.83 \pm 3.09^{\mathrm{b}}$ & \\
\hline
\end{tabular}

There is a statistical difference between columns containing different letters $(\mathrm{p}<0.05)$.

\section{Discussion}

Dog granulocyte anaplasmosis disease (CGA) is a vector-borne infectious disease that occurs by Anaplasma phagocytophilum, which is a mandatory intracellular bacteria found in the Anaplasmataceae family (Chirek et al., 2018).

Although clinical findings are not specific, lethargy, anorexia, pale mucosa, vomiting, polyuria, polydipsia can be seen (Eberts et al., 2011). All dogs in the study group had a history of weight loss, fever, anorexia, polyuria, polydipsia.

The detection of the disease is done by direct blood spreading method, and morulae in neutrophils are observed in up to $60 \%$ of clinical cases (Kohn et al., 2008). However, morulae can also be seen in Ehrlichia ewengii, which infect neutrophils, so other diagnostic methods must be used. Since 2006, ELISA SNAP 4Dx test kit has been used in practice and detects $\operatorname{Ig} M$ and Ig G antibodies against A. phagocytophilum (Shaw et al., 2001).

In one study, fever, high respiratory rate, vomiting, and diarrhea were observed among the first clinical findings in Anaplasma phagocytophilum seropositive dogs. Hematological evaluation revealed thrombocytopenia, leukopenia, lymphopenia and neutropenia. In biochemical analysis, high serum ALT, AST values were obtained (Granick et al., 2009). In another study, severe thrombocytopenia and lymphopenia were observed in hematological evaluation, hemoglobin and hematocrit values were within the normal reference range. In biochemical analysis, ALT and AST values were obtained in the range of normal values with high serum ALP value (Melter et al., 2007). In our study, apart from similar findings, high ALP, AST and ALT values were obtained in serum biochemistry analysis and were found statistically significant $(\mathrm{p}<0.05)$. Also, unlike this 
study, thrombocytopenia is mild and decreases within normal values. Although the mechanism of thrombocytopenia is not fully known, it is thought to be related to the increase in platelet activation and consumption due to the inflammation formed in endothelial cells (Bexfield et al., 2005). In another study, sever thrombocytopenia, leukocytosis and anemia were observed, and it was reported that leukopenia is a less common finding. In serum biochemical analysis results, ALT and ALP values were reported to be high (Jensen et al., 2007). The findings in this study are similar to the findings in our study. As a result of serum biochemical analysis, an increase in ALP, ALT, AST values was observed ( $p<0.05)$. The mechanism of increases in liver transaminases is unknown. It is thought that the increase in transaminase values may be associated with the suppression of the immune system formed due to A. phagocytophilum infection and septicemia caused by secondary infections (Melter et al.; 2007). In addition, as a result of anemia, which is a symptom of the disease, damage to liver, kidney and muscle tissue cells occurs due to hypoxia and it has been reported that it may cause an increase in enzyme values (Costa et al., 2012).

Plier et al. (2009) found intermittent cough with fever, weakness, anorexia, bronchovesicular sounds in thoracic auscultation. It has been reported that severe thrombocytopenia, normocytic normochromic anemia and leukocytosis are seen in blood parameters. Moderately increased ALP has been reported in serum biochemistry analysis. Although cough has been identified in both naturally and experimentally infected dogs with Anaplasma phagocytophilum, pneumonia was documented for the first time in this study. The absence of any organism causing pneumonia in the samples taken from the lung, but the detection of the morulae in the neutrophils obtained from the lungs suggests that pneumonia is caused by $\mathrm{A}$. phagocytophilum.

Hepsidin is a peptide hormone. Because of its antibacterial and antifungal properties, hepcidin was originally identified as an antimicrobial peptide produced in the liver (Krause et al., 2000; Park et al., 2001). However, studies have reported that it is a type II acute phase reactant and plays a role in iron metabolism (Frazer et al., 2002; Nicolas et al., 2002). Hepsidin is responsible for the recycling of iron and the regulation of iron balance. Excessive iron excess stimulates the production of hepcidin and the increase of the hormone decreases the iron concentration, thus preventing excess iron loading. Otherwise, hepcidin is suppressed in iron deficiency. This ensures dietary iron absorption and regeneration of iron stores (Zhang et al., 2009).

Cai et al. (2016) showed that in babies with iron deficiency anemia, hepcidin level increased after treatment. Park et al. (2006) reported an increase in hepcidin levels as a result of erythropoietic activity suppression after treatment with chemotherapy in anemic mice. Park et al. (2001) reported in another study that there was a significant increase in hepcidin levels after iron replacement in anemic mice. While the production of hepcidin is stimulated by the presence of iron and inflammation, it is inhibited in cases of erythropoiesis due to anemia and hypoxia (Falzacappa and Muckenthaler, 2005; Ganz, 2006).

Kali et al. (2015) reported that hepcidin was triggered by IL-6 during inflammation and could be used as an important marker in sepsis and inflammatory reactions. Nemeth et al. (2003) reported that in patients with infection and inflammatory disease, iron overload by transfusion increased the excretion of hepcidin in the urine, and the mRNA of hepcidin was significantly induced by in vitro IL-6. Huang et al. (2017) have been shown to increase the release of hepcidin in the liver tissue of mice whose endotoxemia model was created by injecting lipopolysaccharide. In a study, Şahinduran et al. (2016) reported for the first time that hepcidin value showed a statistically significant difference $(p<0.001)$ in dogs with parvoviral infection compared to healthy ones.

In this study, for the first time, the relationship between some parameters of anemia and hepcidin was investigated in A. phagocytophilum seropositive dogs. As a result of the study, iron value was found as $145.70 \pm 56.51(\mu \mathrm{g} / \mathrm{dL})$ in healthy dogs, and in seropositive dogs with 
A.phagocytophilum was found as $72.50 \pm 17.02$ $(\mu \mathrm{g} / \mathrm{dL})(\mathrm{p}<0.05)$. Hepcidin values were found as $11.83 \pm 3.09(\mu \mathrm{g} / \mathrm{ml})$ in healthy dogs, and in seropositive dogs with A.phagocytophilum was found as $36.16 \pm 12.99(\mu \mathrm{g} / \mathrm{ml})$. In the statistical evaluation between the two groups, the difference between them was found significant $(p<0.05)$. During inflammation caused by anaplasma phagocytophilum infection, various cytokines, especially IL-6, increase the production of hepcidin (Kemna et al., 2005; Wessling-Resnick, 2010). Increased hepcidin levels; It decreases the release of iron from hepatocyte cells and iron absorption by macrophage, leading to decreases in serum iron levels (Orro et al., 2008). Decreases in serum iron levels are thought to cause a decrease in erythropoiesis and cause non-regenerative anemia. In addition, serum Fe levels may have decreased due to the removal of free iron from the circulation by the monocyte / macrophagespecific hemoglobin scavenging receptor mechanism, which binds haptoglobin-hemoglobin $(\mathrm{Hp}-\mathrm{Hb})$ complexes rapidly formed in the circulation after hemolysis of red blood cells and facilitates their uptake (Weinstein et al., 2002; Weaver et al., 2006). According to our results, it has been determined that in anemic dogs infected with A. phagocytophilum, hepcidin can be used as an effective biomarker in combination with other parameters and may help in diagnosis.

\section{Acknowledgements}

This study was supported by Mehmet Akif Ersoy University Scientific Research Projects Commission (Project No: 0572-YL-19).

\section{References}

Bexfield, N.H., Villiers, E.J., Herrtage, M.E., 2005. Immune-mediated haemolytic anaemia and thrombocytopenia associated with Anaplasma phagocytophilum in a dog. Journal of Small Animal Practice 46, 543-548.

Cai, H.J., Wang, N.L., Liu, K.K., Chu, J.H., Wang, Y., Yang, L.H., Wu, Z.Y., 2016. Clinical Significance of Hepcidin in the Diagnosis of Infant Iron Deficiency Anemia. Zhongguo shi yan xue ye xue za zhi 24, 546550
Chirek, A., Silaghi, C., Pfister, K., Kohn, B., 2018. Granulocytic anaplasmosis in 63 dogs: clinical signs, laboratory results, therapy and course of disease. Journal of Small Animal Practice 59, 112-120.

Cockwill, K.R., Taylor, S.M., Snead, E.C., Dickinson, R., Cosford, K., Malek, S., Lindsay, L.R., Diniz, P.P., 2009. Granulocytic anaplasmosis in three dogs from Saskatoon, Saskatchewan Can. Veterinary Journal 50, 835-840.

Costa, M.M., França, R.T., Da Silva, A.S., Paim, C.B., Paim, F., Amaral, C.H.D., Dornelles, G.L., Cunha, J., Soares, J.F., Labruna, M.B., Mazzanti, C.M.A., Silvia, G., Monteiro, G.G., Lopes, S., 2012. Rangelia vitalii: changes in the enzymes ALT, CK and AST during the acute phase of experimental infection in dogs. Revista Brasileira De Parasitologia Veterinaria 21, 243-248.

Coyne, D.W., 2011. Hepcidin: clinical utility as a diagnostic tool and therapeutic target. Kidney International 80 (3), 240-244.

Eberts, M.D., Vissotto de, P., Diniz, P.P., Beall, M.J., Stillman, B.A., Chandrashekar, R., Breitschwerdt, E.B., 2011. Typical and atypical manifestations of Anaplasma phagocytophilum infection in dogs. Journal of the American Animal Hospital Association 47, 86-94.

Falzacappa, M.V.V., Muckenthaler, M.U., 2005. Hepcidin: iron-hormone and anti-microbial peptide. Gene 364, 37-44.

Frazer, D.M., Wilkins, S.J., Becker, E.M., Vulpe, C.D., Mckie, A.T., Trinder, D., Anderson, G.J., 2002. Hepcidin expression inversely correlates with the expression of duodenal iron transporters and iron absorption in rats. Gastroenterology 123, 835-844.

Fry, M.M., Liggett, J.L., Baek, S.J., 2004. Molecular cloning and expression of canine hepcidin, Veterinary Clinical Pathology 33, 223-227.

Ganz, T., 2006. Hepcidin - a peptide hormone at the interface of innate immunity and iron metabolism. In Antimicrobial Peptides and Human Disease, Berlin: Heidelberg Springer, pp: 183-198.

Granick, J.L., Armstrong, P.J., Bender, J.B., 2009. Anaplasma phagocytophilum infection in dogs: 34 cases (2000-2007). Journal of the American Veterinary Medical Association 1559-1565.

Huang, P., Wang, J., Lin, X., Yang, F.F., Tan, J.H., 2017. Effects of IL-10 on iron metabolism in LPSinduced inflammatory mice via modulating hepcidin expression. European Review for Medical and Pharmacological Sciences 21, 3469-3475. 
Jensen, J., Simon, D., Escobar, H.M., Soller, J.T., Bullerdiek, J., Beelitz, P., Nolte, I., 2007. Anaplasma phagocytophilum in dogs in Germany. Zoonoses Public Health 54, 94-101.

Kali, A., Charles, M.V.P., Seetharam, R.S.K., 2015. Hepcidin-A novel biomarker with changing trends. Pharmacognosy Reviews 9, 35.

Kemna, E., Pickkers, P., Nemeth, E., van, d., Hoeven, H., Swinkels, D., 2005. Time-course analysis of hepcidin, serum iron, and plasma cytokine levels in humans injected with LPS. Blood 106, 18641866.

Kohn,. B, Galke, D., Beelitz, P., Pfister, K., 2008. Clinical features of canine granulocytic anaplasmosis in 18 naturally infected dogs. Journal of Veterinary Internal Medicine 22, 1289-1295.

Krause, A., Neitz, S., Mägert, H.J., Schulz, A., Forssmann, W.G., Schulz-Knappe, P., Adermann, K., 2000. LEAP-1, a novel highly disulfide-bonded human peptide, exhibits antimicrobial activity. FEBS Letters 480, 147-150.

Lai, T.H., Kumagai, Y., Hyodo, M., Hayakawa, Y., Rikihisa, Y., 2009. The Anaplasma phagocytophilum $\mathrm{PleC}$ histidine kinase and PleD diguanylate cyclase twocomponent system and role of cyclic Di-GMP in host cell infection. Journal of Bacteriology 191, 693-700.

Lee, S.H., Lee, J.H., Jang, W.J., Koh, S.E., Yang, Y.M., Kim, B.J., Kook, Y.H., Park, K.H., 2003. Differentiation of Borrelia burgdorferi sensu lato through groEL gene analysis. FEMS Microbiology Letters 222, 51-57.

Melter, O., Stehlik, I., Kinska, H., Volfova, I., Ticha, V., Hulinska, D., 2007. Infection with Anaplasma phagocytophilum in a young dog: a case report. Veterinarni Medicina 52, 207-212.

Murata, H., Shimada, N., Yoshioka, M., 2004. Current research on acute phase proteins in veterinary diagnosis. The Veterinary Journal 168, 28-40.

Nemeth, E., Valore, E.V., Territo, M., 2003.

Hepcidin, a putative mediator of anemia of inflammation, is a type II acute-phase protein. Blood 101, 2461-2463.

Nicolas, G., Viatte, L., Bennoun, M., Beaumont, C., Kahn, A., Vaulont, S., 2002. Hepcidin, a new iron regulatory peptide. Blood Cells, Molecules and Diseases 29, 327-335.

Orro, T., Jacobsen, S., LePage, J.P., Niewold, T., Alasuutari, S., Soveri, T., 2008. Temporal changes in serum concentrations of acute phase proteins in newborn dairy calves. The Veterinary Journal 176, 182187.
Park, C.H., Valore, E.V., Waring, A.J., Ganz, T., 2001. Hepcidin, a urinary antimicrobial peptide synthesized in the liver. The Journal of Biological Chemistry 276, 7806-7810.

Petersen, H.H., Nielsen, J.P., Heegaard, P.M., 2004. Application of acute phase protein measurements in veterinary clinical chemistry. Veterinary Research 35, 163-187.

Plier, M.L., Breitschwerdt, E.B., Hegarty, B.C., Kidd, L.B., 2009. Lack of evidence for perinatal transmission of canine granulocytic anaplasmosis from a bitch to her offspring. Journal of the American Animal Hospital Association 45, 232-238.

Prak, M., Lopez, M.A., Gabayan, V.,,Ganz, T., Rivera, S., 2006. Suppression of hepcidin during anemia requires erythropoietic activity. Blood 108, 37303735.

Rikihisa, Y., 2006. New findings on members of the family Anaplasmataceae of veterinary importance. Annals of the New York Academy of Sciences 1078, 438-445.

Sahinduran, S., Albay, M.K., Karakurum, M.C., Ozmen, O., Kale, M., 2016. Investigation of some cytokines, acute phase proteins and hepcidin levels before and after treatment in dogs with parvoviral gastroenteritis. Pakıstan Veterınary Journal 36, 487-492.

Sainz, Á., Roura, X., Miró, G., Estrada-Peña, A., Kohn, B., Harrus, S., Solano-Gallego, L., 2015. Guideline for veterinary practitioners on canine ehrlichiosis and anaplasmosis in Europe. Parasites Vectors 8, 75 .

Shaw, S.E., Day, M.J., Birtles, R.J., Breitschwerdt, E.B., 2001. Tick-borne infectious diseases of dogs. Trends Parasitol 17, 74-80.

Tunç, H.Ö., Aktaş, M.S., 2016. Türkiye'de Köpeklere Kene Aracılığıla Bulaşan Hastalıklar. Erciyes Üniversitesi Veteteriner Fakültesi Dergisi 13, 223-230.

Weaver, L.K., Hintz-Goldstein, K.A., Pioli, P.A., Wardwell, K., Qureshi, N., Vogel, S.N., Guyre, P.M. 2006. "Pivotal Advance: Activation of cell surface Toll-like receptorscauses shedding of the hemoglobin scavenger receptor CD163", Journal of Leukocyte Biology, 80, 26-35.

Weinstein, D.A., Roy, C.N., Fleming, M.D., Loda, M.F., Wolfsdorf, J.I., Andrews, N.C., 2002. Inappropriate expression of hepcidin is associated with iron refractory anemia: implications for the anemia of chronic disease. Blood 100, 3776-3781.

Wessling-Resnick, M., 2010. Iron homeostasis and the inflammatory response. Annual Review of Nutrition 30, 105-122. 
MAKU J. Health Sci. Inst. 2020, 8(3): 90-97.

doi: $10.24998 /$ maeusabed.801923

Zhang, D.L., Hughes, R.M., Ollivierre-Wilson, H., Ghosh, M.C., Rouault, T.A., 2009. A ferroportin transcript that lacks an iron-responsive element enables duodenal and erythroid precursor cells to evade translational repression. Cell Metabolism 9, 461-473. 